\title{
THE INTERDEPENDENCE OF MECHANICAL PROPERTIES AND PETROGRAPHIC CHARACTERISTICS OF ULTRAMAFIC ROCKS FROM GERANIA OPHIOLITIC COMPLEX
}

\author{
Giannakopoulou P.P. ${ }^{1}$, Tsikouras B. ${ }^{\mathbf{1 , 2}}$ and Hatzipanagiotou K. ${ }^{1}$ \\ ${ }^{1}$ University of Patras, Department of Geology, Section of Earth Materials, 265 00, Patras, Greece \\ ${ }^{2}$ Universiti Brunei Darussalam, Faculty of Science, Physical and Geological Sciences, Jalan \\ Tungku Link,Gadong BE1410, Bandar Seri Begawan, Brunei Darussalam
}

\begin{abstract}
Ultramafic rocks from the Gerania Mountain ophiolite were tested as aggregates. Petrographic study through polarizing microscope enabled us to determine the presence of dunite, harzburgite and lherzolite. A series of mechanical tests were carried out in order to determine the suitability of these rocks in a wide range of applications. Dunite and harzburgite samples show higher values of uniaxial compression strength than the lherzolites, as the presence of joints and the higher degree of alteration significantly affects negatively this mechanical property in the last rock-type. The same factors influence the point load index, too. Serpentinization and the presence of soft and laminate minerals also exert a negative influence on the resistance on abrasion and attrition, as well as the grinding of the rocks. The same factors influence negatively the point load index, too.

Keywords: Aggregates, Mechanical properties, Lherzolite, Dunite, Harzburgite.
\end{abstract}

\section{Пєрí}

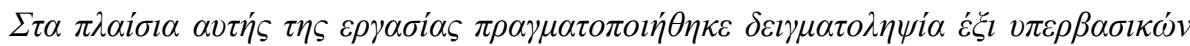

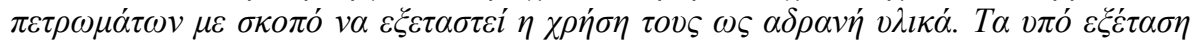

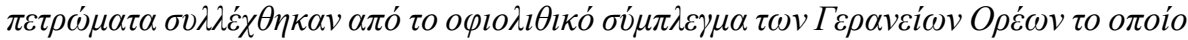

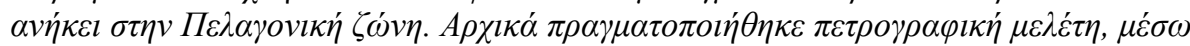

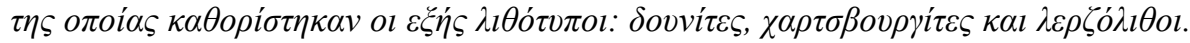

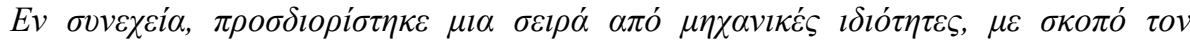

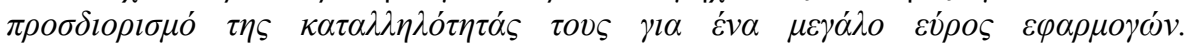

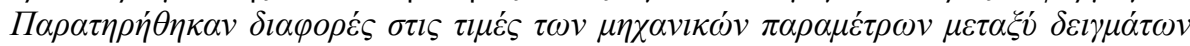

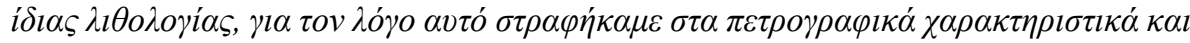

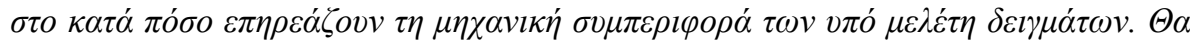

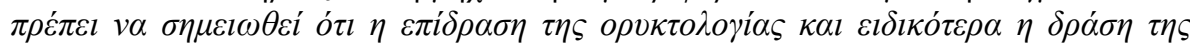

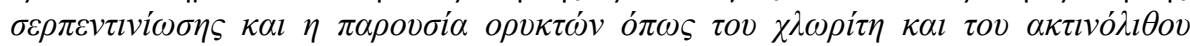

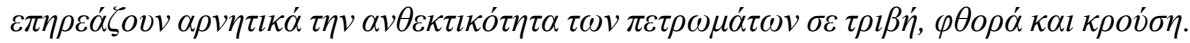

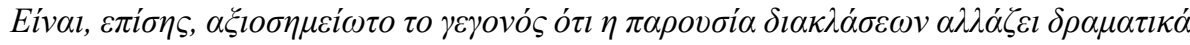

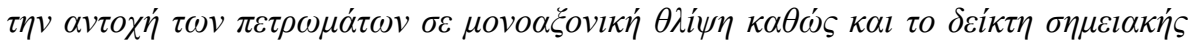

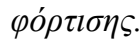

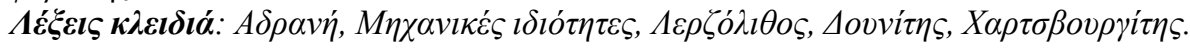




\section{Introduction}

Ophiolites are products of complex tectonic and magmatic processes that operated during the initial rifting through seafloor spreading to subduction-facilitated emplacement stages of ancient oceanic lithospheres. The investigation of the mechanical properties of ophiolitic aggregates is of high significance because of their use in numerous applications, such as concrete, mortar, road bases and sub-bases, bituminous mixtures, railway track ballast, filters and armourstone. Differences in mineralogical and textural characteristics influence the mechanical properties, which vary from excellent to fair (Tugrul and Zarif 1999; Akesson et al., 2001; Lundqvist and Goran, 2001; Miskovsky et al., 2004; Zorlu et al., 2004; Al-Oraimi et al., 2006; Pomonis et al., 2007; Tamrakar et al., 2007; Rigopoulos et al., 2010). This research focuses on the investigation of the mechanical properties of ultramafic rocks, including dunite, lherzolite and harzburgite, and the influence of the modification of their primary petrographic characteristics, due to ocean-floor metamorphism (serpentinization) from Gerania Mountains.

\section{Geological Setting}

Gerania Mountains belong to the Pelagonian geotectonic zone of the internal Hellenides and comprise, from bottom to top, the following succession: a) Sedimentary and volcanic rocks of Permian age (Bornovas et al., 1984); b) a 500 m thick Upper Triassic-Lower Jurassic unit of dark grey neritic limestones and dolomites (Clement, 1971); c) an upper Jurassic succession overlain by either Ammonitico Rosso of Bathonian-Oxfordian age or radiolarian sediments (Clement, 1983); d) ophiolite-derived turbidites (Beotian flysch), occasionally with manganese ore deposits at its bottom; and e) an ophiolite sequence (Fig. 1). The ophiolite is a NE-trending rhomb-shaped outcrop, with approximately $10 \mathrm{~km}$ length and $5 \mathrm{~km}$ width, representing an incomplete and dismembered ophiolite sequence consisting mainly of serpentinized harzburgite, lherzolite and dunite (Fig. 1). Dunite is present at the hypsometrically higher places and is characterized by variable degrees of serpentinization commonly showing a $2-3 \mathrm{~cm}$ thick brown crust due to weathering. Harzburgite comprises a dark lithology affected by variable degrees of alteration and/or weathering, as well as by intense tectonic stress. Lherzolite, which constitutes the dominant lithology of the Gerania peridotites, shows variable but intense serpentinization and contains pyroxenitic dykes $3-4 \mathrm{~cm}$ thick. These serpentinized peridotites are interrupted by gabbro dykes, some of which have been transformed to rodingites. The Gerania ophiolite sequence lacks lavas, cumulates and other lithologies of a typical ophiolitic complex. Fragments of lavas, cumulates and oceanic sediments were found within the melange outcrops and in the detritus in Neogene basins (Kaplanis et al., 2012). An ophiolite mélange that includes fragments of lavas, serpentinized peridotites, gabbros, oceanic sediments, as well as an amphibolite metamorphic sole tectonically underlie the ophiolite. The root zone of the Gerania ultramafic rocks (i.e. Pindos or Axios) and its geochemical signature is poorly constrained (Vacondios, 1997; Danelian and Robertson, 1998).

\section{Analytical methods}

Six polished-thin sections were prepared in order to investigate the mineralogical and textural characteristics of the ultramafic samples using a polarizing microscope. Scanning electron microscopic (SEM) observations and microanalyses were carried out at the Laboratory of Electron Microscopy and Microanalysis, University of Patras, using a Jeol JSM- 6300 SEM, equipped with EDS and WDS and a THETA software in order to determine the chemical composition of primary and secondary minerals. Operating conditions were accelerating voltage $15 \mathrm{kV}$ and beam current $3.3 \mathrm{nA}$ with $4 \mu \mathrm{m}$ diameter beam. Subsequent laboratory tests were performed using the counterpart material of the investigated polished-thin sections. Samples were crushed in a laboratory jaw crusher Retsch BB200 Mangan and they were sieved in order to reach the desired fraction for the LA test, according to ASTM using "B" gradation (ASTM C-131). 


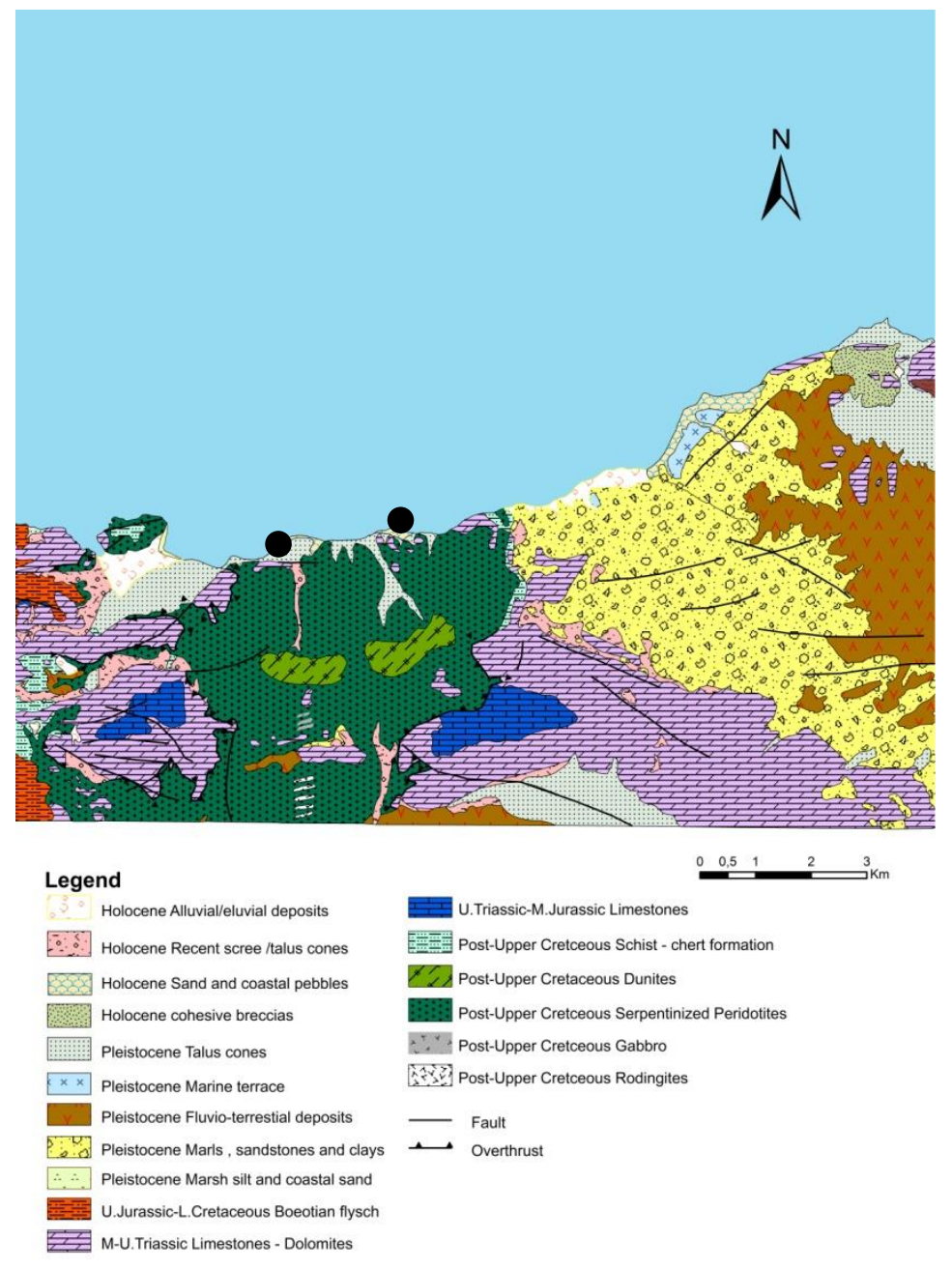

Figure 1 - Geological map of the studied area (Gerania Mountain).

Furthermore, 6 cylindrical rock specimens were prepared with height/diameter ratio between 2 and 3 , and their diameters ranging from 51 to $54 \mathrm{~mm}$ (ASTM D-2938) for the elaboration of uniaxial compressive strength test, and the average values were used for each set of specimens. Six cylindrical and cubic specimens were also prepared for each sample in order to be used for the calculation of the point load index (ISMR (1985).

\section{Results}

\subsection{Petrographic characteristics}

The studied ultramafic samples comprise dunite, harzburgite and lherzolite with variable degrees of serpentinization and deformation. The dunite presents cataclastic and locally granular textures whereas the serpentinized samples show mainly mesh, as well as, local ribbon and interwoven textures. Primary assemblage includes mostly olivine (forsteritic) and scarce relic crystals of orthopyroxene (Figure 2a, b). Infrequent opaque minerals (mainly chromite) are present, too. Serpentine, up to $42 \%$, forms mesh and ribbon textures and is the dominant secondary mineral. It 
is accompanied by chlorite and minor talc; chlorite is frequently observed to surround crystals of chromite.

The harzburgite presents mainly porphyroclastic texture. Its primary assemblage includes olivine, orthopyroxene (most of them with exsolution lamellae of clinopyroxene) and rare clinopyroxene (Figure 2c). Olivine appears as porphyroclasts, which present strong deformation (strain lamellae, kink banding and undulate extinction), as well as small-sized unstrained neoblasts (Figure 2c). Frequent replacement of orthopyroxene from olivine neoblasts is also observed. Chromite is present in small amounts, some of which display rims altered to secondary spinel-type minerals. A dense network of joints occurs in the harzburgite. The serpentine (12\%) comprises the commonest secondary phase presenting ribbon texture; minor chlorite occurs, too.

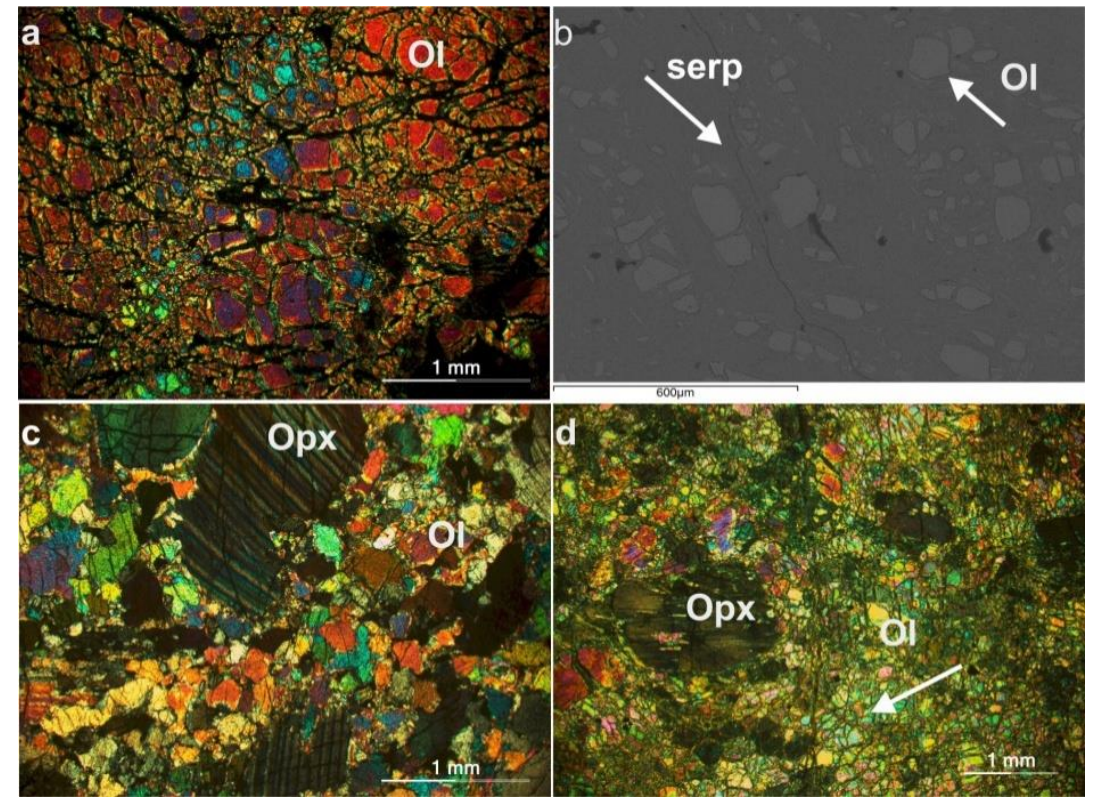

Figure 2 - Petrographic characteristics of the peridotites from the Gerania ophiolite: a. Photomicrograph (XPL) of a dunite (GE 34). b. Backscattered electron image of a serpentinized dunite (GE 17). c. Photomicrograph (XPL) of a harzburgite with strained orthopyroxene crystals (sample GE 28). d. Photomicrograph (XPL) of cataclastic olivine surrounding a relic porphyroclast of orthopyroxene in a lherzolite from Gerania (sample GE 30).Abbreviations: Ol: olivine, Opx: orthopyroxene, serp: serpentine.

The lherzolite shows cataclastic, porphyroclastic and locally protogranular textures, with the primary assemblage including olivine (forsteritic), orthopyroxene and clinopyroxene (Figure 2d). Opaque minerals (mainly Al-spinel) are present in small amounts. Evidence of high-temperature plastic deformation is shown in strained olivine and orthopyroxene porphyroclasts, which display undulate extinction, strain lamellae and kink banding in both orthopyroxene and clinopyroxene (Figure 3a, b). Serpentine is the main secondary mineral ranging from 12 to $75 \%$ of the mode, which shows mostly mesh and ribbon textures (Figure 3c). The effect of serpentinization also leads to the replacement of orthopyroxene from bastite. Some orthopyroxene and clinopyroxene crystals are additionally replaced by chlorite and actinolite. A dense network of joints is also observed in lherzolite (Figure 3d). 

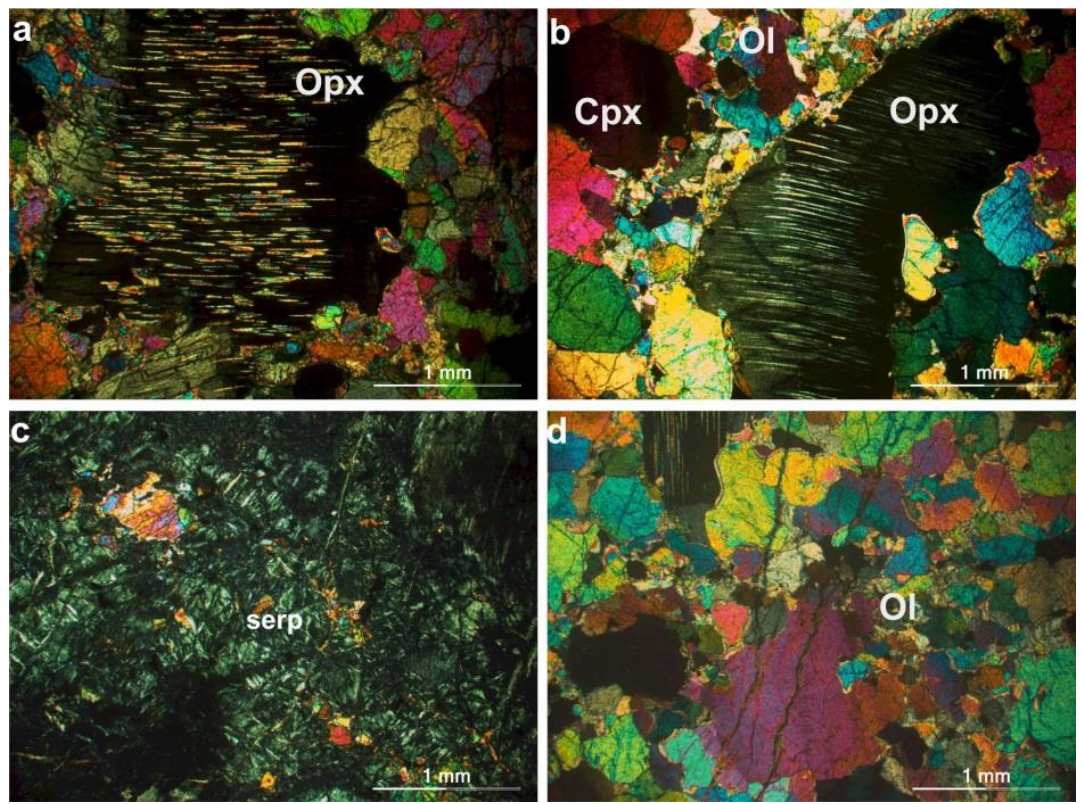

Figure 3 - a. Photomicrograph (XPL) of a lherzolite where exsolution lamellae of clinopyroxene from orthopyroxene is shown (sample GE 36). b. Photomicrograph (XPL) of a

lherzolite showing undulate extinction, strain lamellae and kink banding in crystals of orthopyroxene and clinopyroxene (sample GE 36). c. Photomicrograph (XPL) of a serpentinized lherzolite, with relic olivine and serpentine with mesh texture (sample GE 26). d. Photomicrograph (XPL) of lherzolite transected by an intense network of joints, showing olivine with characteristic undulate extinction (sample GE 36).Abbreviations: Ol: olivine,

Opx: orthopyroxene, Cpx: clinopyroxene, serp: serpentine.

\subsection{Mechanical tests}

The mechanical properties of ultramafic samples were determined by a number of laboratory tests, including the uniaxial compressive strength (UCS), the Los Angeles abrasion value and the point load index. Peridotites with various degrees of serpentinization were chosen in order to study the influence of alteration on their mechanical behaviour. Six cylindrical specimens from each sample were tested for uniaxial compressive strength and the average value was calculated (Table 1). Dunite and harzburgite samples differ from lherzolites in having distinctively higher UCS values. Among lherzolites, the least serpentinized sample GE 30 shows the highest UCS value, while the lherzolitic sample GE 36 presents the lowest value of UCS. However, the most serpentinized dunite GE 17 shows higher value of UCS relative to the fresher GE 34 sample, hence indicating an inconsistent behaviour in terms of alteration.

Table 1 - Results of mechanical tests in the ultramafic rocks from Gerania.

\begin{tabular}{|l|c|c|c|c|}
\hline \multicolumn{1}{|c|}{ Samples } & UCS (MPa) & LA (\%) & Is (50) $(\mathbf{M P a )}$ & $\begin{array}{c}\text { Serpentine } \\
(\boldsymbol{\%})\end{array}$ \\
\hline Dunite (GE 17) & 93.05 & 20.30 & 3.46 & 41.26 \\
\hline Dunite (GE 34) & 88.86 & 17.51 & 5.38 & 28.15 \\
\hline Harzburgite (GE 28) & 86.20 & 15.73 & 2.28 & 12.00 \\
\hline Lherzolite (GE 26) & 66.00 & 19.63 & 3.50 & 75.01 \\
\hline Lherzolite (GE 30) & 75.00 & 16.61 & 3.84 & 28.48 \\
\hline Lherzolite (GE 36) & 50.00 & 23.29 & 1.15 & 12.15 \\
\hline
\end{tabular}


The Los Angeles (LA) abrasion test measures the resistance of an aggregate to impact, abrasion, attrition and grinding. As shown in the Table 1, the results of the LA test range between 15.73 and $23.29 \%$. The harzburgite, as well as the fresh dunite and lherzolite are clearly the most durable samples while the serpentinized peridotites show higher LA values (Table 1). Point load index is considered to be an indirect measurement of the uniaxial compressive strength of samples. Generally, there is a sympathetic relationship of this index to the UCS values in the investigated samples as the fresher ones, with high UCS, show also the highest Is 50 values (Table 1).

\section{Discussion}

In this study, mechanical properties of the investigated ultramafic rocks are correlated with petrographic characteristics using diagrammatic representation and regression analysis (Figure $3 \mathrm{a}, \mathrm{b}$, c). Samples GE 26 and GE 36, which are the most altered peridotites, with quite abundant serpentine,

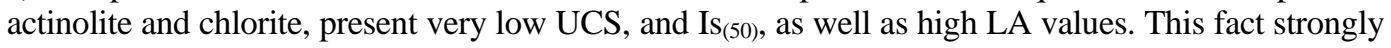
suggests that alteration has a negative effect on the mechanical performance of the rocks as the secondary minerals tend to reduce the coherence of rocks. GE 36, which is the most vulnerable sample includes moreover a dense network of joints, which further lower its quality. Furthermore, the fresh GE 34 dunite displays lower UCS than the altered GE 17 indicating the significant negative influence of the joints in the samples. This is in line with other micropetrographic studies, which have shown that intensely tectonized samples present low values of strength regardless if they are affected by alteration of their primary assemblages or not (Rigopoulos, 2010).

Serpentinization negatively affects the resistance to abrasion, attrition and grinding in our samples as it appears that the highly altered ones show higher LA values as well. Sample GE 36, which is a moderately altered lherzolite, shows the worst LA value, which is assigned to the additional effect of intense fatigue that it has experienced from the occurrence of dense joints. The existence of soft and laminate minerals such as serpentine, chlorite and talc, which behave differentially relative to the hard, prismatic primary minerals (olivine, orthopyroxene, clinopyroxene) explains well the weaker resistance to abrasion, attrition and grinding. The more plastic behaviour of these soft minerals likely absorbs the shocks during the conduction of the LA test, contrary to the hard and brittle primary minerals, hence leading to easier disintegration of the aggregate particles. The variable behaviour of the largely transected samples GE 34 and GE 36, which show low and high LA values, respectively, suggests that the existence of joints doesn't play a determinant role in LA values. This can be explained by the fact that the particles, which are prepared for the conduction of the test, are mostly devoid of joints as these planes of weakness determine the shape of the particles.

Regression analysis was applied for the investigation of the interdependence of the mechanical properties of these ultramafic rocks. Linear regression was used based on the linearity assumption and the determination coefficients $\mathrm{R}^{2}$ and equations of the fitted lines were calculated by the "least squares" method. Other types of relationships were also tested (e.g. logarithmic, power, etc.) but it is always observed that the linear model fits best, giving the highest $\mathrm{R}^{2}$ values. Los Angeles coefficient tended to increase with decreasing uniaxial compressive strength (Fig. 4a) and their correlation is described by the equation:

$$
\mathrm{LA}=-0.1088 \times \mathrm{UCS}+27.171, \mathrm{R}^{2}=0.4057
$$

The negative correlation between the LA coefficient and the UCS in mafic and ultramafic rocks has also been reported previously (e.g. Rigopoulos et al., 2006, 2010) and it indicates that the resistance of the peridotites in attrition and grinding is a linear function of their strength.

Moreover, rather poor correlation exists between LA and $\mathrm{Is}_{(50)}$, which are related through the equation:

Is $50=0.2550 \times \mathrm{LA}+8.091, \mathrm{R}^{2}=0.2468$

This negative correlation suggests generally that the less resistant to abrasion and attrition rocks are also weaker under point load. However, other factors are likely involved in order to explain the poor 
relationship. Although the degree of alteration is a dominant factor that exerts a negative influence on the LA and $\mathrm{Is}_{(50)}$ values, as it has been described by several authors (e.g. Rigopoulos, 2006), the differential impact of joints on the two tests, cannot be ignored. As it was mentioned above LA is not affected by the presence of joints, however, these definitely affect negatively the Is (50) $_{\text {values of }}$ the rocks(Fig. 4b). Hence, it is concluded that the combined effect of alteration and jointing is responsible for the poor correlation shown by LA and $\mathrm{Is}_{(50)}$ tests.

Uniaxial compression strength and point load index show a moderate correlation which can be described by the equation (Fig. 4c):

$\mathrm{UCS}=0.0543 \times \mathrm{Is} 50-0.8874, \mathrm{R}^{2}=0.3809$

Similar positive correlations have been observed also for other ultramafic rocks and several authors have recommended that there is a direct and strong correlation between these two mechanical parameters in rocks (Kurtulus et al., 2011), hence an indirect estimation of one from the other can be made. The moderate correlation shown for the Gerania peridotites indicates that such an estimation involves large errors. This may also be explained by the presence of dense joints and mainly their variable orientation may lead to largely different results particularly for the point load test in the same sample. Mechanical weakness is also largely affected by the presence of actinolite, which is a hard mineral but shows a brittle behavior under stress due to its fibrous crystal habit and its very good cleavage along (110) planes (Rigopoulos et al., 2009). Thus the presence or not and the variable amounts of actinolite in the secondary assemblage of the investigated peridotites is another factor that prevents a good correlation between mechanical properties of the rocks.
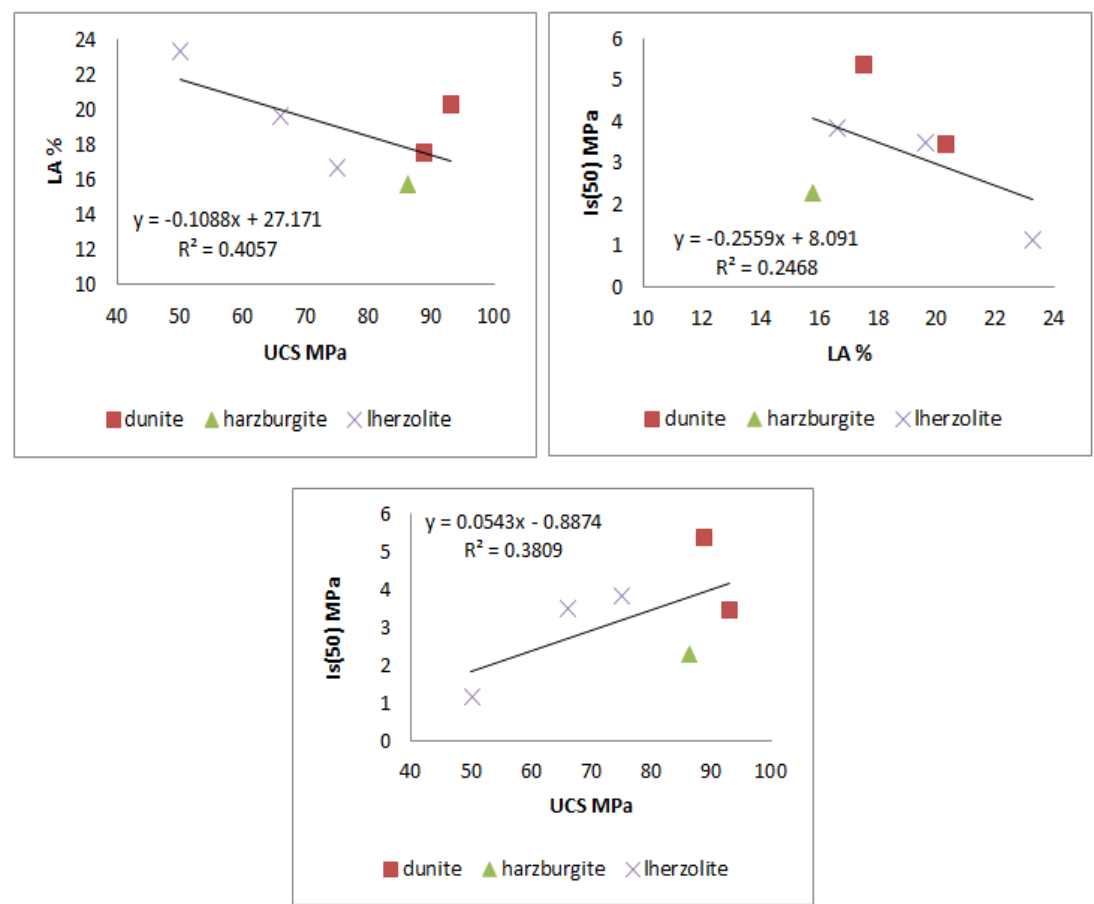

Figure 4 - Correlation of mechanical properties of ultramafic rocks from Gerania: (a) Uniaxial compressive strength (UCS) vs. Los Angeles abrasion value (LA), (b) LA vs. point load index (Is (50), (c) UCS vs. Is (50). 


\section{Conclusions}

- Increasing serpentinization and ocean floor alteration affects negatively the mechanical performance of ultramafic rocks.

- Rocks which contain laminate and soft minerals like chlorite and talc or hard but very brittle phases like actinolite present worse mechanical properties.

- Brittle deformation of rocks affect variably their mechanical strength but it does not play an important role to their resistance to abrasion, attrition and grinding of rocks as the shape of the aggregates is controlled and determined by the original planes of weakness in the rocks.

- Study of the microtextural and mineralogical characteristics of rocks is a determinant factor for the prediction of their mechanical behaviour.

\section{References}

Akesson, U., Lindqvist, J.E., Göransson, M. and Stigh, J., 2001. Relationship between texture and mechanical properties of granites, central Sweden, by use of image-analysing techniques, Bull. Eng. Geol. Environ., 60, 277-284.

Al-Oraimi, S.K., Taha, R. and Hassan, H.F., 2006. The effect of the mineralogy of coarse aggregate on the mechanical properties of high-strength concrete, Constr. Build. Mater., 20, 499-503.

Bornovas, J., Gaitanakis, P. and Spiridopoulos, A., 1984. Geological Map of Greece, 1:50000, Perachora sheet, IGME.

Clément, B., 1971. Découverte d'un flysch éocrétacé en Béotie (Grèce continentale), CR Acad. Sci., 272, 791-792.

Clément, B., 1983. Evolution géodynamique d'un secteur des Hellénides internes: l'Attique-Béotie (Gréce continentale), Thesis Univ Lille I (unpublished).

Danelian, T. and Robertson, A.H.F., 1998. Palaeogeographic implications of the age of radiolarianrich sediments in Beotia (Greece), Bull. Geol. Soc. Greece, 32, 21-29.

Dilek, Y., Furnes, H. and Shallo, M., 2007. Suprasubduction zone ophiolite formation along the periphery of Mesozoic Gondwana, Gondwana Res., 11, 453-475.

Kaplanis, A., Koukouvelas, I., Xypolias, P. and Kokkalas, S., 2012. Kinematics and Ophiolite obduction in the Gerania and Helicon Mountains, Central Greece, Tectonophysics, 215-234.

Kurtulus, C., Bozkurt, A. and Endes, H., 2011. Physical and Mechanical Properties of Serpentinized Ultrabasic Rocks in NW Turkey, Pure Appl. Geophys.

Lundqvist, S. and Göran, M., 2001. Evaluation and interpretation of microscopic parameters versus mechanical properties of Precambrian rocks from the Stockholm region, Sweden. In: Proceedings of 8th Euroseminar on microscopy applied to building materials, 4-7 Sept, Athens.

Miskovsky, K., Taborda Duarte, M., Kou, S.Q. and Lindqvist, PA., 2004. Influence of the mineralogical composition and textural properties on the quality of coarse aggregates, $J$. Mater. Eng. Perform., 13, 144-150.

Pomonis, P., Rigopoulos, I., Tsikouras, B. and Hatzipanagiotou, K. 2007. Relationships between petrographic and physico-mechanical properties of basic igneous rocks from the Pindos ophiolitic complex, NW Greece, Bull. Geol. Soc. Greece, 40, 947-958.

Rigopoulos, I., Tsikouras, B., Pomonis, P. and Hatzipanagiotou, K. 2006. Comparative Evaluation of Dolerites from the Pindos and Vourinos Ophiolitic Rocks for their Use as Aggregates, Tech. Cron. Sci. J. TCG, I, No 3.

Rigopoulos, I., Tsikouras, B., Pomonis, P. and Hatzipanagiotou, K. 2010. The influence of alteration on the engineering properties of dolerites: the examples from the Pindos and Vourinos ophiolites (northern Greece), Int. J. Rock Mech. Min. Sci., 47, 69-80.

Tamrakar, N.K., Yokota, S. and Shrestha, S.D. 2007. Relationships among mechanical, physical and petrographic properties of Siwalik sandstones, Central Nepal Sub-Himalayas, Eng. Geol., 90, 105-123. 
Tuğrul, A. and Zarif, I.H., 1999. Correlation of mineralogical and textural characteristics with engineering properties of selected granitic rocks from Turkey, Eng. Geol., 51, 303-317.

Vacondios, I., 1997. Etude metallogenique des chromites liees aux ophiolites de type Mediterranee occdentale ou orientale: le chromites de Tinos et des Gerannees, Ph.D. thesis, Patras, 98 pp.

Zorlu, K., Ulusay, R., Ocakoglu, F., Gokceoglu, C. and Sonmez, H., 2004. Predicting intact rock properties of selected sandstones using petrographic thin-section data, Int. J. Rock Mech. Min. Sci., 41(1), 93-98. 